\title{
Microgeographic Variation and Inter-Riffle Migration of Rhinichthys atratulus (Pisces: Cyprinidae) in a Small Connecticut Stream, United States
}

\author{
Sage J. Loomis 1,2, Kayla Anatone², Laura Bither ${ }^{1,2}$, Sarah J. Kang², Nola Neri³, David Machado², \\ Michelle L. Kraczkowski', Barry Chernoff ${ }^{1,2,5^{*}}$ \\ ${ }^{1}$ College of the Environment, Wesleyan University, Middletown, USA \\ ${ }^{2}$ Department of Biology, Wesleyan University, Middletown, USA \\ ${ }^{3}$ Department of Molecular Biology and Biochemistry, Wesleyan University, Middletown, USA \\ ${ }^{4}$ Department of Biology, University of Saint Joseph, West Hartford, USA \\ ${ }^{5}$ Department of Earth \& Environmental Sciences, Wesleyan University, Middletown, USA \\ Email: ^bchernoff@wesleyan.edu, sloomis@wesleyan.edu, kanatone@wesleyan.edu,lbither@wesleyan.edu, \\ sjkang@welsyean.edu,nneri@wesleyan.edu,dmachado@wesleyan.edu, mkraczkowski@usj.edu
}

How to cite this paper: Loomis, S.J., Anatone, K., Bither, L., Kang, S.J., Neri, N., Machado, D., Kraczkowski, M.L. and Chernoff, B. (2020) Microgeographic Variation and Inter-Riffle Migration of Rhinichthys atratulus (Pisces: Cyprinidae) in a Small Connecticut Stream, United States. Open Journal of Ecology, 10, 460-481.

https://doi.org/10.4236/oje.2020.107030

Received: June 15, 2020

Accepted: July 14, 2020

Published: July 17, 2020

Copyright (C) 2020 by author(s) and Scientific Research Publishing Inc. This work is licensed under the Creative Commons Attribution International License (CC BY 4.0).

http://creativecommons.org/licenses/by/4.0/

\section{(c) (i) Open Access}

\begin{abstract}
We examined the genetic diversity on a microgeographic scale of Rhinichthys atratulus (Eastern Blacknose Dace) in Allyn Brook, a small tributary in the upper Coginchaug River drainage in Connecticut. By looking at gene flow on a microgeographic scale among populations that had no physical barriers to migration, we tested the null hypothesis that the populations should be homogeneous. We resolved seven polymorphic microsatellite loci and one mitochondrial gene, $n d 2$, in three adjacent populations $(<0.5 \mathrm{~km})$ in Allyn Brook and compared these populations to the two closest populations ( $>5$ $\mathrm{km}$ ) in the Coginchaug River. A dam from the 1920's in lower Allyn Brook has isolated Allyn-Brook populations from Coginchaug-River populations. Allyn Brook was selected because there are only three riffle habitats in the brook and, therefore, there can be no immigration from upstream populations. Each population has private (i.e., unique) alleles and haplotypes, and there are significant genetic differences between all sites. The Allyn Brook populations are almost as different from one another as they are from the distant populations in the Coginchaug River from which they have been isolated for more than 80 years. These results point to in situ evolution and little migration or gene flow among populations on a microgeographic scale. This raises interesting questions for conservation of genetic diversity of stream fishes.
\end{abstract}




\section{Keywords}

Migration, Microgeographic Differentiation, Population Ecology, Gene Flow, Rhinichthys atratulus

\section{Introduction}

One of the prominent features of the Anthropocene has been the disruption of continuous habitat for the world's biota. Understanding how fragmented landscape features affect the maintenance and production of genetic diversity across space and time is critical for conservation biology Anderson, Epperson, Fortin, Holderegger, James, Rosenberg, Scribner and Spear [1] [2]. Riverine systems are ideal to measure how landscape features, such as dams, affect gene flow because of the linear nature of streams. The degree of connectivity among habitats within a watershed is a critical driver of the genetic population structure of freshwater fishes, because barriers to movement limit gene flow and may lead to loss of genetic diversity or even the production of novel genetic signatures [3] [4] [5]. The degree of divergence among populations should increase relative to the number and relative strengths of barriers, and/or the geographic distance that isolates populations [3] [6] [7] [8]. Isolation by distance is expected in riverine fishes but is not always found [9]. Furthermore, freshwater fishes generally have low effective population sizes, which can contribute to high genetic differences among populations in different river drainages [10].

Population genetic structure and migration behavior of riverine fishes have also been studied for ecosystems in which no obvious physical barriers were present. Genetic variation among Poecilia reticulata (Guppy) in Trinidad correlated positively with geographical distance; populations separated by waterfalls were more genetically divergent than those that were not [7]. In a study of the inter-riffle (i.e., rocky habitat where the rocks break the water's surface) movement of five common North American fishes from three families, long corridors between pool habitats, water depth and current were found to limit the amount and rate of fish movement [11].

In our studies of the population structure and ecology of the small riffle-dwelling fish, Rhinichthys atratulus (Eastern Blacknose Dace), we have found large degrees of eco-genetic variation among populations in rivers in Connecticut and in the eastern United States [12] [13]. At a more local scale, populations of $R$. atratulus differed significantly in a western Connecticut river and its tributaries [14].

The present study examines genetic differences among and between populations of $R$. atratulus on a microgeographic scale (Figure 1). The question is, at a microgeographic scale, will the ecology of $R$. atratulus - that is, their easy ability to swim to adjacent habitats-prevent the establishment of novel genetic diversity? At this geographic scale, we expect populations to be genetically homogeneous 


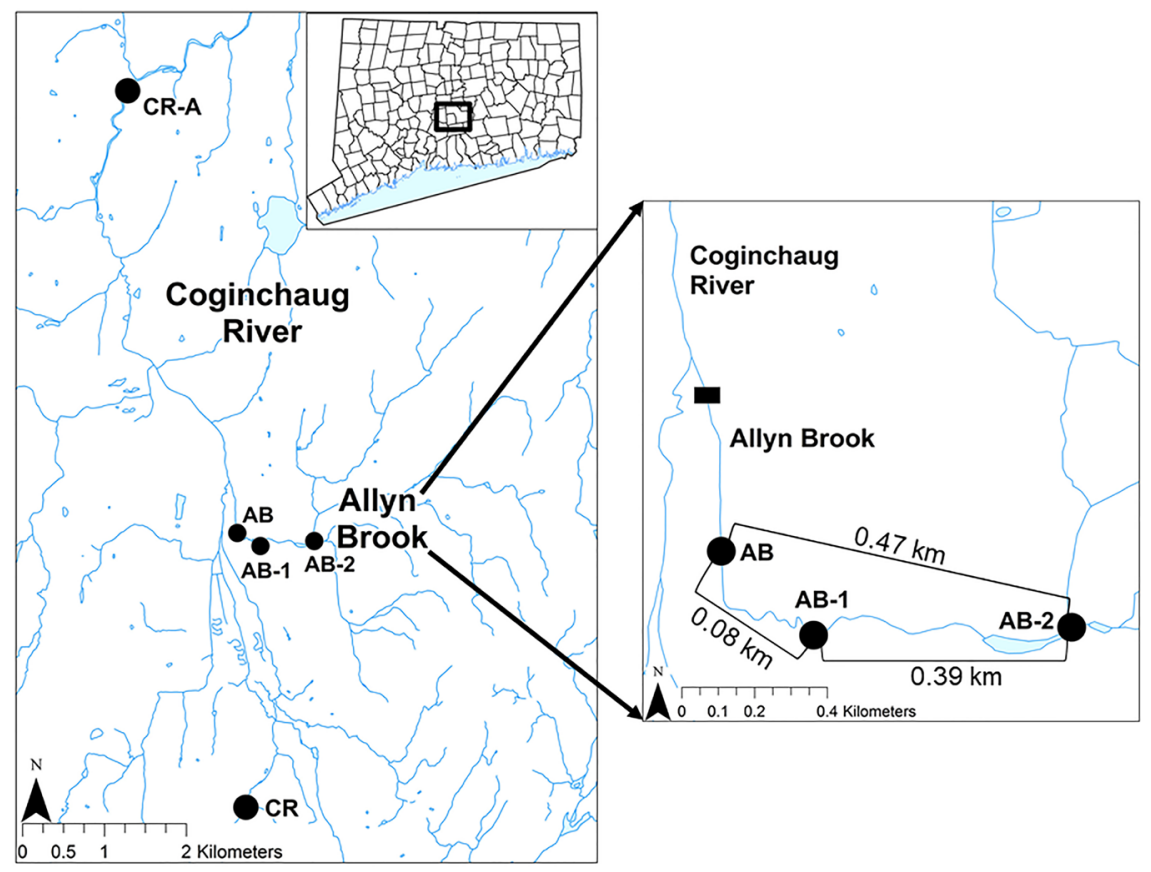

Figure 1. Map of sample locations in Allyn Brook (AB, AB1, AB2) and in the Coginchaug River (CR and CRA) in Connecticut (inset). The Coginchaug River flows from the South to the North; Allyn Brook flows from southeast to the northwest.

because there are no obvious physical barriers to gene flow and movement of fishes among the habitats should prevent the establishment of novel genetic diversity. This is critical because we must be able to distinguish the effects of a naturally patchy environment on a local level from anthropogenic fragmentation of ecosystems.

In this paper we: 1) compare the genetic diversity among $R$. atratulus from adjacent habitats that are isolated in a single small stream (see below); 2) we estimate the migration and mutation rate for each of the populations; 3) we estimate whether the number of individuals in the populations are stable; and 4) we compare the populations from the study sites (Figure 1) to the closest two populations in the river for which the study-site stream is a tributary. The latter is important in order to provide a baseline for an older isolation due to an anthropogenic factor (see below).

\section{Methods}

\subsection{Field Sites}

Allyn Brook, a tributary of the Coginchaug River in central Connecticut, USA (Figure 1), is a small stream with a wetted width less than $4 \mathrm{~m}$ wide (Appendix 1) in the area of sampling. We sampled at three riffles, each less than $3 \mathrm{~m}$ long composed primarily of gravel and sand (Appendix 1) in June 2017. The coordinates of the three riffles - $\mathrm{AB}, \mathrm{AB} 1$ and $\mathrm{AB} 2$ - are given in Appendix 1. The three riffles span a distance of $0.47 \mathrm{~km}$ (Figure 1 ) and there are no physical barriers in between the riffles to prevent or hinder the movements of fishes. A dam 
in the lower part of Allyn Brook from the 1920's [15] has prevented emigration of $R$. atratulus from the Coginchaug River; the backwater of the dam has removed all riffles below our study sites. Above our study sites Allyn Brook changes character and lacks riffle habitats. Thus, the three riffle habitats are the only place in Allyn Brook that the species is found [12].

Physical and chemical characterizations of the three habitats are given in Appendix 1. Conductivity, $\mathrm{pH}$, dissolved oxygen, and water temperature were measured using a Yellow Springs Instrument (YSI) probe Model 556 MPS. At three points along each riffle canopy cover was estimated using a GRS Densitometer. Stream flow velocity was estimated with a Price-Gurley meter at $60 \%$ of the depth. Flow and depth were recorded approximately every meter along the riffle. The riffle slope was measured using a tripod and surveyors rod with a vertical tolerance of $\pm 5 \mathrm{~cm}$. There were no significant differences among the three sites in physical or chemical characteristics.

\subsection{Study Species}

Rhinichthys atratulus (Figure 2) is a small $(<12.5 \mathrm{~cm})$ freshwater riffle-dwelling minnow that lives east of the Appalachian Mountains from Virginia to Nova Scotia [12] [16]. $R$. atratulus tend to live in large populations [16]. They prefer rocky riffles and adjacent pools and of small to medium streams, and can be found in most small streams across Connecticut [17]. They reach maximum length in two to three years, and are an important link in the trophic chain [16] [18]. Rhinichthys atratulus eat primarily invertebrates and plankton, and are important prey to larger fish, especially large brook trout, and fish-eating birds [16] [18]. Rhinichthys atratulus are not broadcast spawners, they bury their eggs in the river substrate adjacent to riffles during spawning [19]. Because of their ubiquitous distribution and trophic importance, they are a useful model organism.

\subsection{Sampling}

Individuals were collected in summer 2016 and 2017, with the number of individuals collected per site as follows: $\mathrm{AB}=34 \mathrm{AB} 1=14$; and $\mathrm{AB} 2=27$ (Appendix 1). Samples were collected via electrofishing. Upper caudal fins clips were

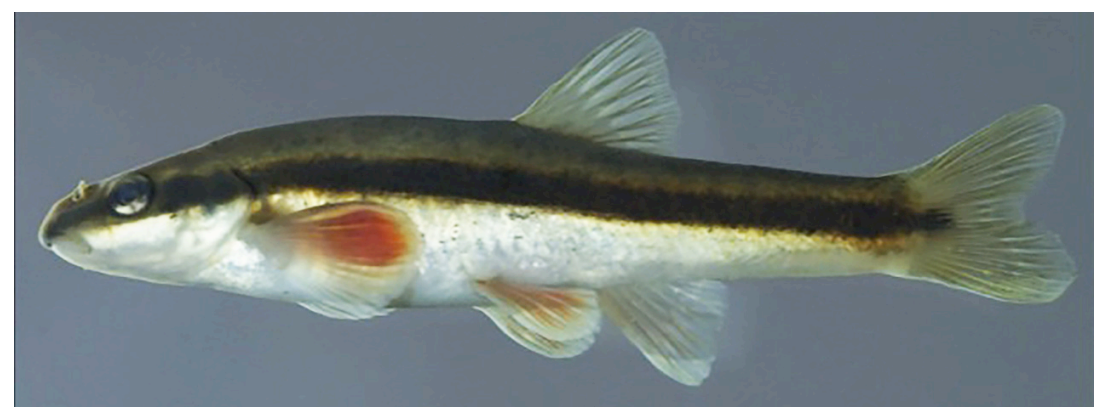

Figure 2. Rhinichthys atratulus, the Eastern Blacknose Dace, $74 \mathrm{~mm}$ total length, breeding male, from the Coginchaug River, CT. Photo by Barry Chernoff. 
taken and stored in 95\% ethanol for subsequent DNA extraction and analysis. Permissions for collecting and handling individuals for scientific study were governed by: CT Scientific Collection Permits SC - 13023 and SC - 17031; IACUC 2015 - 1212 - Chernoff - A, IACUC 2017 - 1212 - Chernoff - A.

\subsection{Molecular Methods}

DNA was extracted from fin clips using the DNeasy blood and tissue kit (QIAGEN Sciences, MD, USA) using the protocol from [12]. The methods and primers used for amplification of the mitochondrial gene $n d 2$ are from Tipton, Gignoux-Wolfsohn, Stonebraker and Chernoff [20]. The fully sequenced $n d 2$ is 1042 base pairs long. After PCR, $7 \mu \mathrm{l}$ of PCR product was mixed with $1 \mu \mathrm{l}$ of Gel Loading Dye and run for 30 minutes on a $2 \%$ agarose gel with $5 \mu$ of SYBRsafe (Invitrogen, Thermo Fischer Scientific). Samples were sequenced at Yale University and purified using their Exo-AP purification protocol. Sequences were aligned using ClustalW multiple alignment in BioEdit v.7.1.7 [21] and manually curated based on chromatograms viewed in FinchTV 1.4 [22]. Curated sequences are available on GenBank under accession numbers MH341914-MH341923, with haplotype 14 added later under MH378685. While Tipton, Gignoux-Wolfsohn, Stonebraker and Chernoff [20] labelled haplotypes by letter, we designate haplotypes by number. Haplotypes $1-38$ correspond to haplotypes all of Tipton, Gignoux-Wolfsohn, Stonebraker and Chernoff [20]; haplotypes not discovered in the previous study [20] begin sequentially with 39. Private haplotypes and microsatellite alleles are defined as those found at only one study site and nowhere else in the distribution of the species [12] [20].

The primers and PCR protocol for amplification of 14 microsatellite loci from non-coding regions are from Kraczkowski and Chernoff [12]. Screening of the microsatellite loci identified seven that were suitably polymorphic for inclusion in this study. Optimization temperatures for loci are as follows: Rhca $15 \mathrm{~b}-60^{\circ} \mathrm{C}$; Rhca16 - 59 ${ }^{\circ} \mathrm{C}$; Rhca20 - $60^{\circ} \mathrm{C}$; BD165 - $47^{\circ} \mathrm{C}$; Ca3 $-45^{\circ} \mathrm{C}$ touchdown procedure; Ca12 - $50^{\circ} \mathrm{C}$; and $\mathrm{BD} 174-60^{\circ} \mathrm{C}$. PCR products were run on a $2 \%$ agarose gel to test for amplification. Samples with definitive bands were sent to the DNA analysis facility of Yale University for fragment analysis. Samples were viewed in Peak Scanner v2.0 [23] to determine the length of microsatellites and possible heterozygotes. Microsatellites were added to GenBank under sequences MH341907-MH34913.

\subsection{Statistical Analyses}

DnaSP v5 10.01 was used to calculate nucleotide and haplotype diversity as well as neutrality tests Tajima's D, Fu and Li's D and Fu's F [24]. Haplotype diversity $(\mathrm{H})$ is the probability of that two randomly-selected haplotypes within a sample are different [24]. Equation (1) is

$$
H=(N / N-1)\left(1-\sum x_{i}^{2}\right)
$$

where $x_{i}^{2}$ is the frequency of each haplotype within a sample and $N$ is the sam- 
ple size. Nucleotide diversity $(\pi)$ is the average number of nucleotide differences per nucleotide site between two DNA sequences in all possible pairs in the sample population [24]. Equation (2) is

$$
\pi=\sum x_{i} x_{j} \tau_{i j}
$$

where $x_{i}$ and $x_{j}$ are the respective frequencies in the $i^{\text {th }}$ and $f^{\text {th }}$ sequences, and $\tau_{i j}$ is the number of nucleotide differences per nucleotide site in the $i^{\text {th }}$ and $f^{\text {th }}$ sequences and summed over all sequences in the sample.

Arlequin 3.5 (with input files generated in DnaSP) was used to generate a haplotype network and to test null hypotheses of genetic homogeneity with analyses of molecular variance (AMOVAs).

The programs PGDSpider [25] and CONVERT [26] were used to generate input files. Arlequin 3.5 [27] and POPGENE [28] generated tests for Hardy-Weinberg equilibrium, Garza-Williamson statistics and AMOVAs. Inbreeding coefficients were calculated as one minus the ratio of the observed over the expected heterozygote frequencies [29].

We used STRUCTUREv2.3.4 to generate a-posteriori Bayesian-likelihood classifications for each individual based upon the genetic signatures of all seven microsatellite loci [30]. STRUCTURE parses individuals into $k$ groups, where $k$ is the number of populations into which individuals are classified. Structure was run three times (one run per $k=1$ to 3 , the number of Allyn Brook populations) with 10,000 burn-ins and 10,000 generations under the admixture model. STRUCTURE was also run with Allyn Brook sites and two samples from the Coginchaug River $(k=1-5)$, one upstream and one downstream of Allyn Brook (CR and CRA in Figure 1). STRUCTURE does not allow the user to assign colors to the genetic groups (Figure 4); it is automatic.

\subsection{Estimation of Migration Rates}

The program Migrate v3.2.1 was used to estimate: the number of migrants per generation [31]; the mutation rate scaled by population size, $\theta$, and [31] the mutation-scaled immigration rates, $M$ [32]. The number of individuals migrating per generation is estimated by $M \times \theta$ [32] [33]. $M$ is a measure of the relative importance of immigration over mutation to bring new variants into the population [32] [33]. Mitochondrial results were run with the DNA sequence model, while microsatellite results were run with the Brownian Motion Model, which is a quicker approximation to the Ladder Model [32]. For both mitochondrial and microsatellite data, the program was run 10 times, and the model with the highest maximum likelihood parameter was selected for further analysis.

\section{Results}

\subsection{Genetic Diversity - $n d 2$}

Eleven haplotypes were identified from the 72 individuals that were sequenced for the $n d 2$ gene from the three Allyn Brook populations. Haplotype 1, hypothesized as the ancestral haplotype of the populations that recolonized the Con- 
necticut River Basin [20], was present at each of the sites but was common in only the upstream locality (Table 1, Figure 3 ). Three additional haplotypes (numbers: 9, 10 and 44) were found at all sites (Table 1) and were an order of magnitude more frequent than the other haplotypes. Five of the 11 haplotypes were private haplotypes (Table 1 ). The middle site, AB1, did not have any private haplotypes. The average haplotype diversity, $\mathrm{Hd}$, for all three sites was 0.801 (range: $0.792 \leq \mathrm{Hd} \leq 0.843)$ and the average nucleotide diversity $(\pi)$ was 0.00237 (range: $0.0023 \leq \pi \leq 0.0024$; Table 2).

Statistics describing haplotype and nucleotide diversity were similar among all sites (Appendix 2). Tests of neutrality (Tajima's D, Fu's F, and Fu and Li's D) were not significant $(P>0.05$, Appendix 2$)$, indicating that there have not been recent bottlenecks, population expansions or non-random eco-evolutionary forces [34] [35] [36].

The parsimony network (Figure 3 ) shows the relationships among the haplotypes. Haplotypes 9, 10 and 37 are known to be widely distributed in the Connecticut River watershed [20]; whereas, haplotypes 10 and 44 are known only from the Coginchaug River drainage [20] (K. Anatone, Wesleyan University,

Table 1. Haplotype frequency, number of haplotypes, number of private haplotypes and microsatellite alleles and sample size for each population. "Private" indicates that the given allele or haplotype is only found at that site. Haplotype 1 is the ancestral haplotype (Haplotype A) from Tipton et al. (2011).

\begin{tabular}{cccc}
\hline & \multicolumn{2}{c}{ Frequency in Population } & \\
\hline Haplotype ID Number & AB & AB1 & 0.154 \\
\hline 1 & 0.0312 & 0.0714 & 0.192 \\
9 & 0.156 & 0.143 & 0.154 \\
10 & 0.281 & 0.357 & 0.0769 \\
14 & 0.0625 & 0 & 0 \\
37 & 0.0625 & 0 & 0.308 \\
44 & 0.344 & 0.357 & 0 \\
47 & 0.0312 & 0 & 0 \\
48 & 0.0312 & 0 & 0.0385 \\
49 & 0 & 0.0714 & 0.0385 \\
50 & 0 & 0 & 0.0385 \\
51 & 0 & 0 & 8 \\
\# Haplotypes & 8 & 5 & 2 \\
\# Private Haplotypes & 3 & 0 & 50 \\
\# Alleles for 7 Loci & 59 & 43 & $7.1 \pm 5.1$ \\
Mean Alleles \pm S.D. & $8.4 \pm 6.4$ & $6.1 \pm 4.2$ & 6 \\
\# Private Alleles & 10 & 3 & \\
Sample Size & 34 & & \\
\hline
\end{tabular}

${ }^{a} \mathrm{~N}=13$ and 26 for two of seven microsatellite loci, respectively. 
Table 2. Modified Garza-Williamson Statistics with sample size (N), mean and standard deviations (s.d.).

\begin{tabular}{cccc}
\hline & AB & AB1 & AB2 \\
\hline Rhca15b & 0.286 & 0.286 & 0.286 \\
Rhca16 & 0.500 & 1.000 & 0.750 \\
Rhca20 & 0.467 & 0.400 & 0.333 \\
Bd165 & 0.667 & 0.600 & 0.500 \\
Ca3 & 0.288 & 0.382 & 0.342 \\
Ca12 & 0.500 & 0.500 & 0.417 \\
Bd174 & 0.500 & 0.385 & 0.482 \\
N & 34 & $14^{\mathrm{a}}$ & $27^{\mathrm{a}}$ \\
Mean & 0.458 & 0.508 & 0.444 \\
s.d. & 0.134 & 0.239 & 0.156 \\
\hline
\end{tabular}

${ }^{\mathrm{a}} \mathrm{N}=13$ and 26 for two of seven microsatellite loci, respectively.

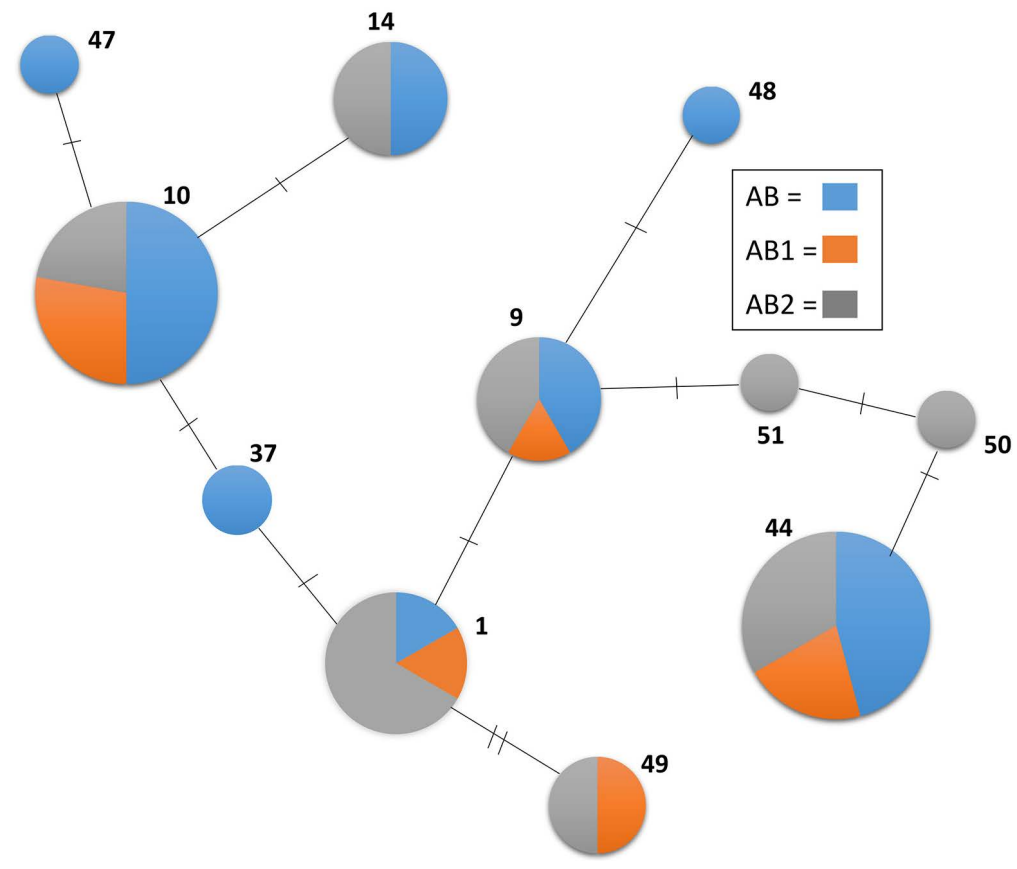

Figure 3. Haplotype Network. The relative size of the circles represents the number of individuals with that haplotype. Perpendicular small lines represent the number of nucleotide changes between haplotypes. The haplotype numbers are given. Haplotypes 37, 47, 48,50 , and 51 are private (i.e. unique) haplotypes.

CT, unpubl. data). When the haplotype network (Figure 3 ) is rooted at the ancestral haplotype (haplotype 1), three evolutionary branches are evident, each with some haplotypes endemic to Allyn Brook (haplotypes 47 - 51). Unlike the "starburst" patterns elucidated by Tipton, Gignoux-Wolfsohn, Stonebraker and Chernoff [20], the topology is well structured with a number of intermediate haplotypes, two of which are endemic to Allyn Brook (haplotypes 50, 51). 


\subsection{Genetic Diversity - Microsatellites}

Seventy-five individuals were sequenced for seven polymorphic microsatellite loci. The frequencies of all alleles for each locus and site are given in Appendix 3. With the exception of Rhca15b and Rhca16, the allelic diversity was large both within and among sites (Table 1; Appendix 3). Two loci, Bd174 and Ca3, exhibited 20 alleles among sites (Appendix 3). The individuals from $\mathrm{AB}$ were the most variable (Table 1) exhibiting 16 and 17 alleles for the latter two loci, respectively (Appendix 3). There were 19 private alleles among the sites (Table 1).

There were seven significant deviations from Hardy-Weinberg (H-W) equilibrium (Appendix 4). Three significant deviations from $\mathrm{H}-\mathrm{W}$ are due to heterozygote deficits. Three inbreeding coefficients for the four deficits range from 0.13 to 0.80 . As the rate of inbreeding increases, the value of the coefficient approaches 1.0 [29]. The effects of inbreeding within populations of small sizes can rapidly decrease the number of heterozygotes produced within each generation [29]. The locus Rhca15b exhibits a significant excess of heterozygotes in each population (Appendix 4) and was fixed at two sites (Appendix 3). This may imply non-random ecological or evolutionary processes acting on this locus [37]; however, other effects may have pronounced effects on small populations, such as genetic drift.

Garza-Williamson statistics estimate whether populations have reduced recently in size or have gone through bottlenecks (Garza and Williamson 2001). For seven or more loci, values less than 0.68 indicate that the population has gone through a recent reduction in size [38]. The means and standard deviations of the modified for each locus and each population (Table 2). Although seven loci were examined, an outlier allele can skew the value of the statistic [38]. With the exception of three values that equal or exceed 0.68 , all other values are well below 0.68 (Table 2).

\subsection{Population Differences - Global AMOVA's}

Global AMOVA's were calculated among Allyn Brook sites as well as between the two Coginchaug River sites and Allyn Brook sites (Table 3). Each of the Allyn Brook sites differed significantly from one another for microsatellites $(p<$ $0.0001)$. For $n d 2$, the two downstream sites (AB vs. AB1) did not differ significantly; all other comparisons were significant $(p<0.0001)$. Allyn Brook flows into the Coginchaug River. The comparison of the Allyn Brook sites to the two Coginchaug River sites indicates that populations from the two streams differ significantly for both microsatellites and for $n d 2$.

\subsection{Bayesian Classification of Individuals from Microsatellite Data}

The maximum likelihood classification model for Allyn Brook populations with the best fit was for two genetic groups ( $k=2$; Figure 4 upper). The Bayesian classification of individuals showed clinal variation among the Allyn Brook sites. 
Table 3. Global AMOVA between Allyn Brook (AB) and Coginchaug River (CR) sites. Significance levels calculated from 1023 random permutations and adjusted subsequently by sequential Bonferroni procedure.

\begin{tabular}{ccccccc}
\hline \multicolumn{3}{c}{ Microsatellites } & & \multicolumn{3}{c}{ nd2 } \\
\hline Comparisons & $\begin{array}{c}\text { Sum of } \\
\text { squares }\end{array}$ & $\begin{array}{c}\text { Variance } \\
\text { components }\end{array}$ & $\begin{array}{c}\text { Percent } \\
\text { Variation }\end{array}$ & $\begin{array}{c}\text { Sum of } \\
\text { squares }\end{array}$ & $\begin{array}{c}\text { Variance } \\
\text { components }\end{array}$ & $\begin{array}{c}\text { Percent } \\
\text { Variation }\end{array}$ \\
\hline AB v AB1 & 17.578 & 0.2211 & $9.45281^{* * *}$ & 0.491 & 0.00769 & 0.63979 \\
AB v AB2 & 31.797 & 0.2645 & $11.490^{* * *}$ & 2.21 & 0.03828 & $3.1326^{* * *}$ \\
AB1 v AB2 & 6.339 & 0.0857 & $4.37^{* * *}$ & 1.035 & 0.02541 & $2.1352^{*}$ \\
All AB sites & 40.544 & 0.0215 & $9.6136^{* * *}$ & 2.668 & 0.0279 & $2.307^{* * *}$ \\
CR sites vs. AB sites & 174.392 & 0.3654 & $14.684^{* * *}$ & 21.846 & 0.1443 & $13.72^{* * *}$ \\
\hline
\end{tabular}

${ }^{\star} P<0.01,{ }^{* *} P<0.001,{ }^{* * *} P<0.0001$.
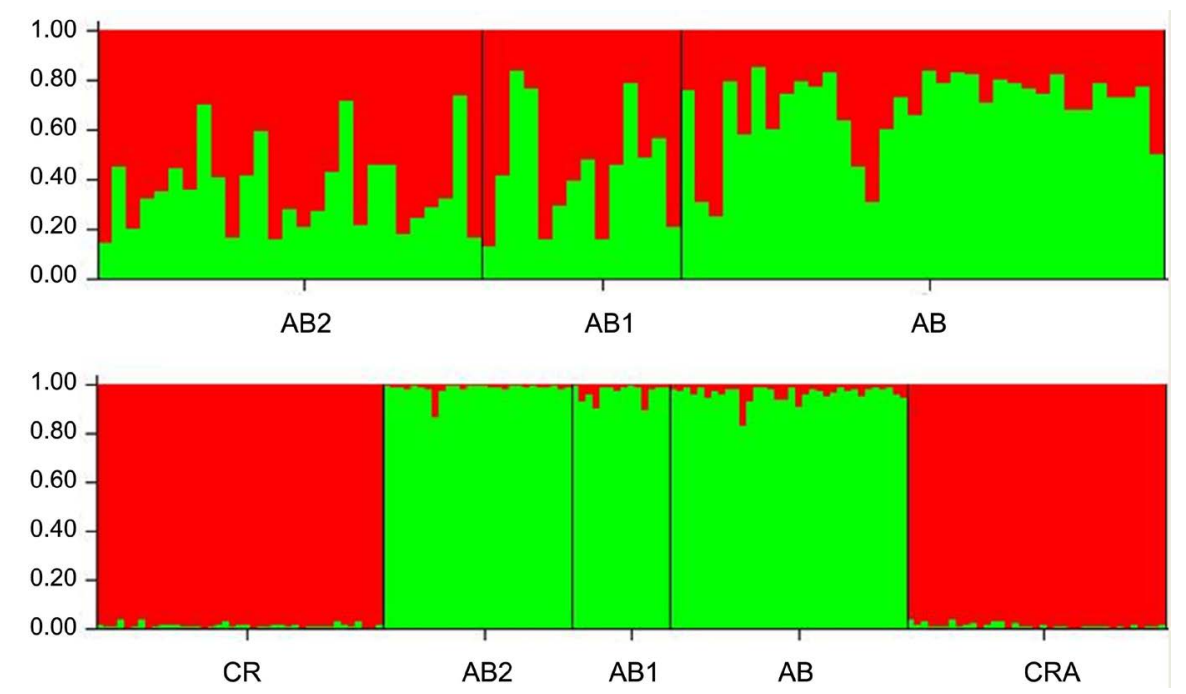

Figure 4. Results of Bayesian classification analysis (STRUCTURE) of Allyn Brook and Coginchaug populations of $R$. atratulus. Each vertical bar represents an individual and the colors represent different genetic groups, the vertical axis indicates the probability that an individual belongs to a given group. The results shown in both parts of the figures are for $k=2$ (i.e. two groups), which were the largest maximum likelihood solutions for both analyses. Upper: results for $\mathrm{AB}, \mathrm{AB} 1$ and $\mathrm{AB} 2$ sites. Lower: comparison of Allyn Brook and Coginchaug sites (CR and CRA). Unfortunately, STRUCTURE does not give control of color selection to the user. The red and green genetic groups in the upper and lower figures are not the same genetic groups.

The following are the percentage of individuals with a $>50 \%$ probability of belonging to the one genetic group (shown as red in Figure 4 upper): $\mathrm{AB}=$ $11.76 \% ; \mathrm{AB} 1=50 \%$, and $\mathrm{AB} 2=81.48 \%$.

We calculated the classification probabilities by adding microsatellite data from populations in the nearby Coginchaug River (CR and CRA), the two closest sampled populations to Allyn Brook populations; the Coginchaug and the Allyn Brook populations have been separated from each other for at least 80 years because of the dam (Figure 1). There were two genetic groups $(k=2)$ (Figure 4). The results identified two distinct genetic groups - one with the Co- 
ginchaug River populations and one with the populations from Allyn Brook.

\subsection{Estimation of Migration Rates}

The number of migrants per generation was estimated from both the $n d 2$ and microsatellite data (Table 4). Among the sites, migrants per generation for microsatellites ranged from 1.5 to 6.6, while migrants per generation for nd2 ranged from 1.1 to 10.7. The average of the downstream direction for migrants per generation was 5.0 and 2.3 for microsatellites for $n d 2$, respectively. The upstream average was 3.3 and 4.9 for microsatellites and $n d 2$, respectively. Potential upstream or downstream biases in migration were tested using a two-tailed T-Test, and no significant difference in direction of stream flow was found.

The population with the lowest $\theta$, or estimated population-scaled mutation rate, for microsatellites was $\mathrm{AB} 1(\theta=0.091)$ and for $n d 2$ was $\mathrm{AB} 2(\theta=0.0036)$. Using $A B 1$ as an example, this means that we expect there will be 9.1 mutations per 100 individuals in the next generation over all sampled loci. $A B$ and $A B 2$ had the highest $\theta$ s for microsatellites $(\theta=0.098)$; $\mathrm{AB} 1$ was highest for $n d 2(\theta=$ $0.0 .0042)$. The $\theta$ s for microsatellites were an order of magnitude larger than those for $n d 2$, indicating more rapid evolution of the former.

The values of $M$ are relative within data type (Table 4 ) and estimated the importance of immigration of genes over mutation to introduce new variants into a population. Gene flow due to immigration was more important than mutation for introducing: 1) microsatellite alleles into $\mathrm{AB} 1$ from $\mathrm{AB} 2$; and 2) $n d 2$ haplotypes into $\mathrm{AB} 1$ from $\mathrm{AB}$.

\section{Discussion}

We examined the structure among populations of $R$. atratulus, in order to assess gene flow on a microgeographic scale. Importantly due to a dam placed near the mouth of Allyn Brook in the 1920's [15] the populations have been isolated from

Table 4. Estimates of migration rates per generation and mutation-scaled immigrations rates, $\mathrm{M}$, for populations from Allyn Brook. The arrows indicate the direction of migration point toward the recipient population. The models for microsatellite and nd2 data with the highest maximum likelihood scores out of 10 runs are shown.

\begin{tabular}{ccccc}
\hline & Microsatellites & \multicolumn{2}{c}{ nd2 } \\
\hline & Migrants per Generation & $\mathbf{M}$ & Migrants per Generation & $\mathbf{M}$ \\
\hline $\mathrm{AB} 2 \Rightarrow \mathrm{AB}$ & 3.54 & 36.02 & 1.078 & 300.4 \\
$\mathrm{AB} 1 \Rightarrow \mathrm{AB}$ & 2.958 & 30.098 & 3.82 & 58.6 \\
$\mathrm{AB} \Rightarrow \mathrm{AB} 2$ & 6.573 & 67.339 & 10.667 & 343.3 \\
$\mathrm{AB} \Rightarrow \mathrm{AB} 1$ & 1.949 & 21.345 & 2.081 & 909.6 \\
$\mathrm{AB} 2 \Rightarrow \mathrm{AB} 1$ & 8.533 & 93.456 & 2.867 & 262.6 \\
$\mathrm{AB} 1 \Rightarrow \mathrm{AB} 2$ & 1.467 & 15.023 & 1.101 & 913.1 \\
Maximum Likelihood & -1213.46 & & -5799.16 & \\
\hline
\end{tabular}


populations in the main river for more than 80 years. Furthermore, there are no physical barriers to movement among the riffles that we sampled and the three riffles are the only remaining habitat for our study species.

We discovered a number of private alleles and haplotypes suggesting that migration and gene flow among populations was insufficient to prevent in situ evolution and the establishment of novel genes in the populations. We expected the middle site, $\mathrm{AB} 1$, to display the greatest effects of migration and geneflow. In fact, $A B 1$ has no private haplotypes, which could have been due to small sample size. But $A B 1$ had private alleles though the fewest (Table 1). Site AB has the largest sample size and the most private alleles and haplotypes, which could indicate that the number of private alleles and haplotypes are a function of sample size. Rarefaction analyses did not show that to be the case. Also, AB's estimated population-scaled mutation rate, $\theta$, was an order of magnitude higher than $\mathrm{AB} 1$ or $A B 2$, indicating that either in situ evolution or differential extinction was primarily responsible for novel alleles in $\mathrm{AB}$.

Maximum-likelihood analyses of migration provide evidence for limited gene flow through the exchange of less than 11 individuals per generation among all sites, with slightly fewer individuals on average migrating upstream than downstream (Table 4). Although the estimated migration of nd2 among populations is, on average, higher than estimations for microsatellites, we suggest that the estimates (Table 4) are overestimates because the analyses of migration ignore historical/phylogenetic information about genes that are currently in high frequency in populations. For example, because Haplotype 1 is the ancestral haplotype for $R$. atratulus in the Connecticut River drainage [20]. The presence of Haplotype 1 in Allyn Brook populations is not result of current gene flow but rather that of post-glacial colonization. A similar case inheres for haplotypes 44 and 10 that had the highest frequencies in all populations (Figure 3, Table 1).

The results of AMOVAs and Bayesian a posteriori classifications of Allyn Brook individuals show that all three populations differed significantly in their genetic signatures consistent with low levels of estimated migration and gene flow among populations (Table 3, Figure 4). Furthermore, Allyn Brook populations differed significantly from nearby populations in the Coginchaug River (Table 3, Figure 4) to the extent that $100 \%$ of all individuals from the two rivers had an almost $100 \%$ probability (mode $=99 \%$ ) of belonging to a genetic group unique to each river. The results indicate that: 1) gene flow among Allyn Brook populations is limited and not sufficient to prevent in situ differentiation; and 2) that the isolation of Allyn Brook populations from Coginchaug River populations over the last $80+$ years has resulted in larger genetic distinctions among populations. These results are consistent with findings from several species of Rhinichthys [12] [20] [39] [40] [41] and other related North American cyprinids, e.g., Phoxinus and Gila [42] [43] that revealed cryptic genetic diversity and inter- or intra-basin genetic diversity, suggesting little or no current gene flow. However, these studies were performed on larger spatial scales, on the order of km's. In microgeographic studies $(\leq 1 \mathrm{~km})$, high levels of genetic diversity and 
limited to no gene flow was found among populations of Salmo trutta (Brown Trout), Cottus gobio (Bullhead), and Craterocephalus stercumuscarum (FlySpeckeled Hardyhead) from the U.S., U.K. and Australia, respectively. There is support for limited gene flow among populations in the absence of barriers over microgeographic scales.

There is only weak evidence to suggest a relationship between geographic distance and genetic differences. At the largest geographic scale, the genetic distances between Allyn Brook populations and Coginchaug River populations would be consistent with an isolation by distance model. Within Allyn Brook, there are only three populations and mathematically no relationship could be calculated. However, the transition between the two microsatellite genetic signatures identified in the Bayesian classification analysis (Figure 4 upper) varied clinally with distance. Isolation by distance has been difficult to identify in river fishes [9], depending upon such factors as stream size and body size [44] as well as habitat preference. Rhinichthys atratulus is a relatively small minnow $<12.5$ $\mathrm{cm}$ total length, living in a small stream, $<2.5 \mathrm{~m}$ wide with limited proclivity for migrating.

We present six hypotheses for why gene flow is low even on such a small geographic scale: 1) The fish are not moving between populations; 2) fish are moving but not mating and, therefore, not exchanging genetic material; 3 ) migrating fish are preyed upon in the long sandy channels between riffle habitats; 4) fish migrate but upon some density threshold of encounters with neighboring dace return to the original site (F. Cohan, pers. comm.); 5) only individuals that possess common haplotypes or microsatellite alleles migrate, or individuals with private haplotypes or alleles have minimal rates of migration, such that we cannot detect migration with genetic data; or 6) all fish are migrating, but private haplotypes and alleles are selected against in the new habitat. We dismiss hypothesis 6 as unlikely because statistical tests failed to identify non-random processes (Appendix 2) and the microsatellite loci are for the most part in Hardy-Weinberg equilibrium (Appendix 4). The four significant heterozygote deficits were likely due to inbreeding (inbreeding coefficients ranged from 0.13 to 0.80). Because the riffle habitats of the Allyn Brook sites are virtually identical in size, substrate, chemistry, forest overhang and flow, we dismiss hypothesis 6-there should not be significant differences in any selection regimes among riffle sites. At this time there is no evidence to support or refute hypotheses 2, 4 and 5.

There is some support in the literature for hypothesis 1 . The restricted movement paradigm states that resident stream fishes tend to be relatively sedentary [45]. However, there are data to show that some stream species move more often and farther than thought previously when movements are measured directly [46] [47]. In estimating movements, mark and recapture studies can be ambiguous due to low capture rates. While low recapture rates may imply significant movement, high turnover rates or large population sizes in a restricted area would yield similar results [48]. Gerking [45]) proposed a movement range of 20 - $50 \mathrm{~m}$ for midwestern U.S. stream fishes. The median individual displacement 
in the majority of trout populations studied by Rodríguez [48] fell within this range: a median of ca. $5 \mathrm{~m}$ in Oncorhynchus clarki (Cutthroat Trout) and up to $90 \mathrm{~m}$ in Salvelinus fontinalis (Brook Trout). In our study, sample sites were 80 $470 \mathrm{~m}$ apart. Perhaps that these sites are too far apart for $R$. atratulus to move through open channels. There were no individuals of $R$. atratulus found between the three riffles and these are the only riffles in Allyn Brook.

Lonzarich, Lonzarich and Warren Jr [11] hypothesized that long riffles and water velocity regimes can limit the daily inter-habitat movement of stream fishes. Two sympatric congeners from New Zealand, Galaxias gollumoides with strong habitat preference for discontinuous habitats of low-velocity water had larger mean DNA sequence divergence and higher among-population differentiation than an undescribed congener that lives in faster-moving water [49]. The migratory Luciobarbus comizo (Iberian Barbel) adjusted their behavior in response to small stream barriers, and remained within $1000 \mathrm{~m}$ of initial capture sites even though the barbels could easily pass the barriers [50]. Rhinichthys atratulus is a riffle-dwelling species, preferring slightly faster moving water over rocky substrates, and seems to regard the runs (long, slow-moving river segments) as barriers to movement. We have never captured dace in between riffles despite multiple samplings.

It is also possible that $R$. atratulus are preyed upon in the runs between riffle habitats (hypothesis 3). In observations of the fishes in Allyn Brook, there were high numbers of large $(>18 \mathrm{~cm}$ ) Semotilus corporalis (Fallfish), known as a predator of $R$. atratulus [51], swimming actively in the runs. Furthermore, sites in Allyn Brook were fairly open, and not shaded by trees, exposing fishes to piscivorous birds [52]. In Allyn Brook, three piscivorous bird predators, Megaceryle alcyon (Belted Kingfishers), Ardea herodias (Great Blue Heron) and Butorides virescens (Green Heron) are common (B. Chernoff, pers. observ.). Predation by birds may often be overlooked. Predators such as Great Blue Herons and Belted Kingfishers have the potential to significantly impact community dynamics and trophic structure of aquatic prey species [53].

Larson, Hoffman et al. 2002 inferred in a study over several that $R$. obtusus (Western Blacknose Dace; the sister group of $R$. atratulus) (Kraczkowski and Chernoff 2014) had established a robust population in a neighboring creek in Arkansas. They labelled the suspected emigres as "dispersers". Clearly, $R$. atratulus is capable of migrating, even long distances, for example, the post-glacial colonization of the Connecticut River basin from south of New York [20]. But it is also clear that on a microgeographic scale, something important is limiting gene flow among populations in Allyn Brook allowing for separate population-genetic structures to establish.

The genetic differentiation of populations on a microgeographic scale has important implications for conservation of biodiversity. The Evolutionary Significant Unit (ESU), first proposed by Ryder (1986) has been expanded upon importantly by Moritz [54] and Casacci, Barbero and Balletto [55]. The idea is to 
recognize the importance of genetic diversity below the level of species. The idea that populations with highly fragmented distributions might be separate ESUs is gaining some popularity [55] [56]. If the haplotype network (Figure 3) is rooted at Haplotype 1 as per Tipton, Gignoux-Wolfsohn, Stonebraker and Chernoff [20], then there are at least three distinct lineages; the divergence of nuclear microsatellite alleles is well described above and the populations are distinct from their nearest neighbors in the Coginchaug River (Table 3, Figure 4 lower). As more species are examined at microgeographic scales, such as that by Nash, Kraczkowski and Chernoff [8], we predict that divergence and structuring patterns of the type demonstrated herein will become the norm rather than the exception. If we recognize evolutionary potential as suggested by Tim, Anne, Boyd, Micah, Douglas, Aaron and Bonnie [56], then populations meeting the other criteria of Moritz [54] will be recognized as ESU's-a situation we would agree with but may be impractical. We do suggest that focusing upon habitat preservation at landscape levels can also help protect unique and valuable genetic diversity.

\section{Conclusion}

At a microgeographic scale, there does not seem to be a point where populations of Rhinichthys atratus are genetically homogeneous. This is demonstrated for both microsatellite and haplotype data. There were large numbers of private alleles and haplotypes within each of the sampled populations. The high numbers of private haplotypes and alleles indicate low rates of migration and gene flow and high in situ evolution within populations. Maximum likelihood estimations of the population genetic models developed by Beerli [57] reveal an average of only a few migrating individuals per generation. Our data suggest that patchiness of habitat in the absence of obvious barriers can lead to significant within-species eco-evolutionary divergence.

\section{Acknowledgements}

We are grateful to Joel LaBella, Laurie Kenney, Valerie Marinelli, Virginia Harris, Diane Meredith, Blanche Meslin and Suzanne Bussolari for all the help with field gear, arranging and accounting for supplies, shipping samples, etc., that we so depend upon. We are grateful to Fred Cohan for his insightful comments on a draft of the manuscript. SL, LB, SK, DM, and NN received funding from undergraduate internship programs of the College of the Environment and the College of Integrated Sciences. BC received from Schumann Funds, Biology Department and College of the Environment, and project grants from Academic Affairs, Wesleyan University to undertake this study. All of the procedures involving the collection and handling of fishes were humane and ethical, and were approved by state and animal care and use committees: CT Scientific Collection Permits

SC-13023 and SC-17031; IACUC 2015-1212-Chernoff-A, IACUC 2017-1212Chernoff-A. 


\section{Conflicts of Interest}

The authors declare no conflicts of interest regarding the publication of this paper.

\section{References}

[1] Anderson, C.D., Epperson, B.K., Fortin, M.J., Holderegger, R., James, P.M.A., Rosenberg, M.S., Scribner, K.T. and Spear, S. (2010) Considering Spatial and Temporal Scale in Landscape-Genetic Studies of Gene Flow. Molecular Ecology, 19, 3565-3575. https://doi.org/10.1111/j.1365-294X.2010.04757.x

[2] Gomez-Uchida, D., Knight, T.W. and Ruzzante, D.E. (2009) Interaction of Landscape and Life History Attributes on Genetic Diversity, Neutral Divergence and Gene Flow in a Pristine Community of Salmonids. Molecular Ecology, 18, 4854-4869. https://doi.org/10.1111/j.1365-294X.2009.04409.x

[3] Dias, M.S., Cornu, J.F., Oberdorff, T., Lasso, C.A. and Tedesco, P.A. (2013) Natural Fragmentation in River Networks as a Driver of Speciation for Freshwater Fishes. Ecography, 36, 683-689. https://doi.org/10.1111/j.1600-0587.2012.07724.x

[4] Kanno, Y., Vokoun, J.C. and Letcher, B.H. (2011) Fine-Scale Population Structure and Riverscape Genetics of Brook Trout (Salvelinus fontinalis) Distributed Continuously along Headwater Channel Networks. Molecular Ecology, 20, 3711. https://doi.org/10.1111/j.1365-294X.2011.05210.x

[5] Thomas, E.D., Corey, D.A., Paul, C.M. and Michael, S.R. (2015) Population Structure in the Roundtail Chub (Gila robusta Complex) of the Gila River Basin as Determined by Microsatellites: Evolutionary and Conservation Implications. PLOS ONE, 10, e0139832. https://doi.org/10.1371/journal.pone.0139832

[6] Boizard, J., Magnan, P. and Angers, B. (2009) Effects of Dynamic Landscape Elements on Fish Dispersal: The Example of Creek Chub (Semotilus atromaculatus). Molecular Ecology, 18, 430-441. https://doi.org/10.1111/j.1365-294X.2008.04044.x

[7] Crispo, E., Bentzen, P., Reznick, D.N., Kinnison, M.T. and Hendry, A.P. (2006) The Relative Influence of Natural Selection and Geography on Gene Flow in Guppies. Molecular Ecology, 15, 49-62. https://doi.org/10.1111/j.1365-294X.2005.02764.X

[8] Nash, C.M., Kraczkowski, M.L. and Chernoff, B. (2017) Insight into the Population Structure of Hardhead Silverside, Atherinomorus stipes (Teleostei: Atherinidae), in Belize and the Florida Keys Using nd2. Ecology and Evolution, 7, 9503-9517. https://doi.org/10.1002/ece3.3457

[9] Crookes, S. and Shaw, P.W. (2016) Isolation by Distance and Non-Identical Patterns of Gene Flow within Two River Populations of the Freshwater Fish Rutilus rutilus (L. 1758). Conservation Genetics, 17, 861-874.

https://doi.org/10.1007/s10592-016-0828-3

[10] McGlashan, D.J. and Hughes, J.M. (2000) Reconciling Patterns of Genetic Variation with Stream Structure, Earth History and Biology in the Australian Freshwater Fish Craterocephalus stercusmuscarum (Atherinidae). Molecular Ecology, 9, 1737-1751. https://doi.org/10.1046/j.1365-294x.2000.01054.x

[11] Lonzarich, D.G., Lonzarich, M.R. and Warren Jr, M.L. (2000) Effects of Riffle Length on the Short-Term Movement of Fishes among Stream Pools. Canadian Journal of Fisheries and Aquatic Sciences, 57, 1508-1514.

https://doi.org/10.1139/f00-082

[12] Kraczkowski, M.L. and Chernoff, B. (2014) Molecular Phylogenetics of the Eastern and Western Blacknose Dace, Rhinichthys atratulus and $R$. obtusus (Teleostei: Cy- 
prinidae). Copeia, 2014, 325-338. https://doi.org/10.1643/CG-14-002

[13] Anatone, K., Bither, L., Nash, C., Meyer, A.M., Neri, N., Loomis, S., Kraczkowski, M.L. and Chernoff, B. The Effects of Waterfalls and Riffles on the Genetic Population Structure and Evolution of Rhinichthysatratulus, Eastern Blacknose Dace (Teleostei: Cyprinidae) in the Mattabesset River Drainage, CT, USA. (In Press)

[14] Anatone, K., Baumann, Z., Mason, R.P., Hansen, G. and Chernoff, B. (2020) Century-Old Mercury Pollution: Evaluating the Impacts on a Local Fish from the Eastern United States. Chemosphere, 259, Article ID: 127484. (In Press) https://doi.org/10.1016/j.chemosphere.2020.127484

[15] Heinemann, R. (2012) Understanding Stream Habitat and Biota within the Context of Past and Present Land Use. Master's Thesis, Wesleyan University, Middletown.

[16] Scott, W.B. and Crossman, E.J. (1973) Freshwater Fishes of Canada. Ottawa, Fisheries Research Board of Canada, Ottawa.

[17] Jacobs, R.P.O.D. and Eileen (2009) A Pictorial Guide to Freshwater Fishes of Connecticut. Connecticut Department of Environmental Protection, Hartford.

[18] Rollwagen, J. and Stainken, D. (1980) Ectoparasites and Feeding Behavior of the Blacknose Dace, Rhinichthys atratulus (Cyprinidae: Cypriniformes) Hermann. The American Midland Naturalist, 103, 185-190. https://doi.org/10.2307/2425053

[19] Jenkins, R.E.B. and Noel, M. (1993) Freshwater Fishes of Virginia. American Fisheries Society, Bethesda.

[20] Tipton, M.L., Gignoux-Wolfsohn, S., Stonebraker, P. and Chernoff, B. (2011) Postglacial Recolonization of Eastern Blacknose Dace, Rhinichthys atratulus (Teleostei: Cyprinidae), through the Gateway of New England. Ecology and Evolution, 1, 343-358. https://doi.org/10.1002/ece3.31

[21] Hall, T.A. (1999) BioEdit v7.1.7. A User Friendly Biological Sequence Alignment Editor and Analysis Program for Windows 95/98/NT. Nucleic Acids Symposium Series, 41, 95-98.

[22] Geospiza.com (2015) Finch TV. https://digitalworldbiology.com/FinchTV

[23] Biosystems, A. (2006) Peak Scanner: Fragment Analysis Software v2.0.

[24] Librado, P.A.R.J. (2009) DnaSP v5: A Software for Comprehensive Analysis of DNA Polymorphism Data. Bioinformatics, 25, 1451-1452. https://doi.org/10.1093/bioinformatics/btp187

[25] Lischer, H.E.L. and Excoffier, L. (2012) PGDSpider: An Automated Data Conversion Tool for Connecting Populations Genetics and Genomics Programs. Bioinformatics, 28, 298-299. https://doi.org/10.1093/bioinformatics/btr642

[26] Glaubitz, J.C. (2004) CONVERT: A User-Friendly Program to Reformat Diploid Genotypic Data for Commonly Used Population Genetic Software Packages. Molecular Ecology, 4, 309-310. https://doi.org/10.1111/j.1471-8286.2004.00597.x

[27] Excoffier, L. (2010) Arlequin V3.5.2.2. A New Series of Programs to Perform Population Genetic Analyses under Linux and Windows. Molecular Ecology Resources, 10, 564-567. https://doi.org/10.1111/j.1755-0998.2010.02847.x

[28] Yeh, F.C., Boyle and Timothy, B.J. (1997) Popgene v1.3. Population Genetics Analysis of Co-Dominant and Dominant Markers and Quantitative Traits. Belgian Journal of Botany, 129, 157.

[29] Hartl, D.L. and Clarke, A.G. (2007) Principles of Population Genetics. Sinauer Associates, Sunderland.

[30] Pritchard, J., Stephens, M. and Donnelly, P. (2000) Structure v2.3.4. 
[31] Ferraro, J.V., Plummer, T.W., Pobiner, B.L., Oliver, J.S., Bishop, L.C., Braun, D.R., Ditchfield, P.W., Seaman, J.W., III, Binetti, K.M., Seaman, J.W., Jr., Hertel, F. and Potts, R. (2013) Earliest Archaeological Evidence of Persistent Hominin Carnivory. PLOS ONE, 8, e62174. https://doi.org/10.1371/journal.pone.0062174

[32] Beerli, P. (2009) How to Use Migrate or Why Are Markov Chain Monte Carlo Programs Difficult to Use? Conservation Biology, 17, 42-79. https://doi.org/10.1017/CBO9780511626920.004

[33] Beerli, P. and Palczewski, M. (2010) Unified Framework to Evaluate Panmixia and Migration Direction among Multiple Sampling Locations. Genetics, 185, 313-326. https://doi.org/10.1534/genetics.109.112532

[34] Fu, Y.X. and Li, W.H. (1993) Statistical Tests of Neutrality of Mutations. Genetics, 133, 693.

[35] Ramírez-Soriano, A., Ramos-Onsins, S.E., Rozas, J., Calafell, F. and Navarro, A. (2008) Statistical Power Analysis of Neutrality Tests under Demographic Expansions, Contractions and Bottlenecks with Recombination. Genetics, 179, 555-567. https://doi.org/10.1534/genetics.107.083006

[36] Tajima, F., Misawa, K. and Innan, H. (1998) The Amount and Pattern of DNA Polymorphism under the Neutral Mutation Hypothesis. An International Journal of Genetics and Evolution, 102, 103-107. https://doi.org/10.1007/978-94-011-5210-5_10

[37] Waples, R. (2015) Testing for Hardy-Weinberg Proportions: Have We Lost the Plot? The Journal of Heredity, 106, 1-19. https://doi.org/10.1093/jhered/esu062

[38] Garza, J. and Williamson, E. (2001) Detection of Reduction in Population Size Using Data from Microsatellite Loci. Molecular Ecology, 10, 305-318. https://doi.org/10.1046/j.1365-294x.2001.01190.x

[39] Billman, E.J., Lee, J.B., Young, D.O., McKell, M.D., Evans, R.P. and Shiozawa, D.K. (2010) Phylogenetic Divergence in a Desert Fish: Differentiation of Speckled Dace within the Bonneville, Lahontan, and Upper Snake River Basins. Western North American Naturalist, 70, 39-47. https://doi.org/10.3398/064.070.0105

[40] Hoekzema, K. and Sidlauskas, B.L. (2014) Molecular Phylogenetics and Microsatellite Analysis Reveal Cryptic Species of Speckled Dace (Cyprinidae: Rhinichthys osculus) in Oregon's Great Basin. Molecular Phylogenetics and Evolution, 77, 238-250. https://doi.org/10.1016/j.ympev.2014.04.027

[41] Wiesenfeld, J.C., Goodman, D.H. and Kinziger, A.P. (2018) Riverscape Genetics Identifies Speckled Dace (Rhinichthys osculus) Cryptic Diversity in the Klamath-Trinity Basin. Conservation Genetics, 19, 111-127. https://doi.org/10.1007/s10592-017-1027-6

[42] Dowling, T.E., Broughton, R.E. and Demarais, B.D. (1997) Significant Role for Historical Effects in the Evolution of Reproductive Isolation: Evidence from Patterns of Introgression between the Cyprinid Fishes, Luxilus cornutus and Luxilus chrysocephalus. Evolution, 51, 1574-1583. https://doi.org/10.1111/j.1558-5646.1997.tb01480.x

[43] Toline, C.A. and Baker, A.J. (1995) Mitochondrial DNA Variation and Population Genetic Structure of the Northern Redbelly Dace (Phoxinus eos). Molecular Ecology, 4, 745-754. https://doi.org/10.1111/j.1365-294X.1995.tb00275.x

[44] Radinger, J. and Wolter, C. (2014) Patterns and Predictors of Fish Dispersal in Rivers. Fish \& Fisheries, 15, 456-473. https://doi.org/10.1111/faf.12028

[45] Gerking, S.D. (1959) The Restricted Movement of Fish Populations. Biological Re- 
views, 34, 221-242. https://doi.org/10.1111/j.1469-185X.1959.tb01289.x

[46] Larson, G.L., Hoffman, R.L. and Moore, S.E. (2002) Observations of the Distributions of Five Fish Species in a Small Appalachian Stream. Transactions of the American Fisheries Society, 131, 791-796. https://doi.org/10.1577/1548-8659(2002)131<0791:OOTDOF>2.0.CO;2

[47] Gowan, C., Young, M.K., Fausch, K.D. and Riley, S.C. (1994) Restricted Movement in Resident Stream Salmonids: A Paradigm Lost? Canadian Journal of Fisheries and Aquatic Sciences, 51, 2626-2637. https://doi.org/10.1139/f94-262

[48] Rodríguez, M.A. (2002) Restricted Movement in Stream Fish: The Paradigm Is Incomplete, Not Lost. Ecology, 83, 1-13. https://doi.org/10.1890/0012-9658(2002)083[0001:RMISFT]2.0.CO;2

[49] Waters, J. and Burridge, C.P. (2016) Fine-Scale Habitat Preferences Influence Within-River Population Connectivity: A Case-Study Using Two Sympatric New Zealand Galaxias Fish Species. Freshwater Biology, 61, 51-56. https://doi.org/10.1111/fwb.12675

[50] Branco, P., Amaral, S.D., Ferreira, M.T. and Santos, J.M. (2017) Do Small Barriers Affect the Movement of Freshwater Fish by Increasing Residency? Science of the Total Environment, 581-582, 486-494. https://doi.org/10.1016/j.scitotenv.2016.12.156

[51] Johnson, J.H., Nack, C.C. and Chalupnicki, M.A. (2009) Predation by Fallfish (Semotilus corporalis) on Pacific Salmon Eggs in the Salmon River, New York. Journal of Great Lakes Research, 35, 630-633. https://doi.org/10.1016/j.jglr.2009.08.001

[52] Gelwick, F.P., Stock, M.S. and Matthews, W.J. (1997) Effects of Fish, Water Depth, and Predation Risk on Patch Dynamics in a North-Temperate River Ecosystem. Oikos, 80, 382-398. https://doi.org/10.2307/3546606

[53] Steinmetz, J., Kohler, S.L. and Soluk, D.A. (2003) Birds Are Overlooked Top Predators in Aquatic Food Webs. Ecology, 84, 1324-1328. https://doi.org/10.1890/0012-9658(2003)084[1324:BAOTPI]2.0.CO;2

[54] Moritz, C. (1994) Defining Evolutionary-Significant-Unites for Conservation. Trends in Ecology \& Evolution, 9, 373-375. https://doi.org/10.1016/0169-5347(94)90057-4

[55] Casacci, L.P., Barbero, F. and Balletto, E. (2013) The "Evolutionarily Significant Unit" Concept and Its Applicability in Biological Conservation. Italian Journal of Zoology, 81, 182-193. https://doi.org/10.1080/11250003.2013.870240

[56] Tim, L.K., Anne, P.H., Boyd, E.K., Micah, C.K., Douglas, L.P., Aaron, W.A. and Bonnie, L.B. (2014) A Nuclear DNA Perspective on Delineating Evolutionarily Significant Lineages in Polyploids: The Case of the Endangered Shortnose Sturgeon (Acipenser brevirostrum). PLoS ONE, 9, e102784. https://doi.org/10.1371/journal.pone.0102784

[57] Beerli, P. (2007) Estimation of the Population Scaled Mutation Rate from Microsatellite Data. Genetics, 177, 1967-1968. https://doi.org/10.1534/genetics.107.078931 


\section{Appendices}

Appendix 1. Collection information from Allyn Brook localities. Negative values indicate western longitudes. The conductance of the water is given in millisiemens/cm (mS). Water chemistry and flow were measured over four days in August 2018.

\begin{tabular}{|c|c|c|c|}
\hline Measurement & $\mathrm{AB}$ & $\mathrm{AB} 1$ & $\mathrm{AB} 2$ \\
\hline Sample Size (N) & 34 & 14 & 27 \\
\hline Longitude & -72.688381 & -72.687974 & -72.684713 \\
\hline Latitude & 41.474908 & 41.474312 & 41.473926 \\
\hline Mean Depth $(\mathrm{cm})$ & 15.75 & 14.93 & 15.33 \\
\hline Mean Wetted Width (m) & 3.95 & 2.67 & 3.72 \\
\hline Riffle Length m & 2.31 & 2.43 & 2.59 \\
\hline Substrate $\%$ gravel & 33 & 33 & 33 \\
\hline Substrate \% sand & 32 & 31 & 32 \\
\hline Discharge $\left(\mathrm{m}^{3} / \mathrm{s}\right)$ & 0.291 & 0.293 & 0.290 \\
\hline Riffle slope\% & 0.036 & 0.037 & 0.037 \\
\hline \% Canopy & 0 & 0 & 1.0 \\
\hline Mean Temperature $\left({ }^{\circ} \mathrm{C}\right)$ & 22.78 & 22.79 & 22.78 \\
\hline Conductivity $\mathrm{mS}$ & 0.201 & 0.205 & 0.197 \\
\hline $\mathrm{DO}(\mathrm{ml} / \mathrm{L})$ & 11.10 & 11.05 & 11.10 \\
\hline $\mathrm{pH}$ & 7.13 & 7.13 & 7.12 \\
\hline
\end{tabular}

Appendix 2. Diversity statistics and tests of neutrality and non-random eco-evolutionary processes.

\begin{tabular}{ccccccccc}
\hline Location & $\begin{array}{c}\text { \# of } \\
\text { Haplotypes }\end{array}$ & $\begin{array}{c}\text { Haplotype } \\
\text { Diversity }\end{array}$ & $\begin{array}{c}\text { Nucleotide } \\
\text { Diversity }\end{array}$ & $\begin{array}{c}\text { Avg \# of Nucleotide } \\
\text { Differences between } \\
\text { haplotypes }\end{array}$ & $\begin{array}{c}\text { Tajima's } \\
\text { D }\end{array}$ & Fu's F & $\begin{array}{c}\text { Fu and } \\
\text { Li's D }\end{array}$ \\
\hline $\mathrm{AB}$ & 8 & 0.792 & 0.0024 & 2.484 & 0.74947 & -0.432 & 0.03257 \\
$\mathrm{AB} 1$ & 5 & 0.769 & 0.0024 & 2.527 & 0.54701 & 0.668 & 0.20809 \\
$\mathrm{AB} 2$ & 8 & 0.843 & 0.0023 & 2.412 & 0.47368 & -0.945 & 0.10999 \\
\hline
\end{tabular}

Appendix 3. Allele frequencies for the seven polymorphic microsatellite loci from three Allyn Brook localities. Diploid sample sizes $(2 \mathrm{~N})$ follow: $\mathrm{AB}=68 ; \mathrm{AB} 1=28 ; \mathrm{AB} 2=54$.

\begin{tabular}{cccc}
\hline Allele & \multicolumn{3}{c}{ Localities } \\
\hline RHCA15b & $\mathrm{AB}$ & $\mathrm{AB} 1$ & $\mathrm{AB} 2$ \\
\hline 1 & 0.500 & 0.500 & 0.444 \\
2 & 0.500 & 0.500 & 0.556 \\
\hline $\mathrm{RHCA16}$ & $\mathrm{AB}$ & $\mathrm{AB} 1$ & $\mathrm{AB} 2$ \\
\hline 1 & 0.985 & 0.962 & 0.907 \\
2 & & 0.038 & 0.056 \\
3 & 0.015 & & 0.037 \\
\hline
\end{tabular}




\section{Continued}

\begin{tabular}{|c|c|c|c|}
\hline RHCA20 & $\mathrm{AB}$ & $\mathrm{AB} 1$ & $\mathrm{AB} 2$ \\
\hline 1 & 0.662 & 0.714 & 0.833 \\
\hline 2 & 0.015 & 0.036 & \\
\hline 3 & 0.015 & 0.036 & 0.019 \\
\hline 4 & 0.059 & & \\
\hline 5 & 0.044 & 0.036 & 0.019 \\
\hline 6 & 0.132 & 0.143 & 0.074 \\
\hline 7 & 0.074 & 0.036 & 0.056 \\
\hline BD165 & $\mathrm{AB}$ & $\mathrm{AB} 1$ & $\mathrm{AB} 2$ \\
\hline 1 & 0.147 & 0.786 & 0.926 \\
\hline 2 & 0.324 & 0.036 & \\
\hline 3 & 0.426 & 0.178 & 0.037 \\
\hline 4 & 0.103 & & 0.037 \\
\hline BD174 & $\mathrm{AB}$ & $\mathrm{AB} 1$ & $\mathrm{AB} 2$ \\
\hline 1 & & 0.036 & \\
\hline 2 & 0.074 & 0.143 & 0.096 \\
\hline 3 & 0.088 & 0.143 & 0.173 \\
\hline 4 & 0.221 & 0.176 & 0.077 \\
\hline 5 & 0.147 & 0.107 & 0.269 \\
\hline 6 & 0.044 & 0.143 & 0.058 \\
\hline 7 & 0.074 & & 0.058 \\
\hline 8 & 0.015 & 0.0357 & \\
\hline 9 & 0.044 & & \\
\hline 10 & 0.088 & 0.1071 & 0.0385 \\
\hline 11 & 0.015 & & \\
\hline 12 & 0.029 & & 0.0385 \\
\hline 13 & 0.029 & & 0.0769 \\
\hline 14 & 0.029 & 0.071 & 0.019 \\
\hline 15 & 0.059 & 0.036 & 0.039 \\
\hline 16 & & & 0.019 \\
\hline 17 & & & 0.019 \\
\hline 18 & & & 0.019 \\
\hline 19 & 0.029 & & \\
\hline 20 & 0.15 & & \\
\hline $\mathrm{CA} 3$ & $\mathrm{AB}$ & $\mathrm{AB} 1$ & $\mathrm{AB} 2$ \\
\hline 1 & & 0.036 & 0.019 \\
\hline 2 & & & 0.019 \\
\hline 3 & 0.056 & 0.071 & 0.039 \\
\hline 4 & 0.044 & 0.036 & 0.019 \\
\hline 5 & 0.103 & 0.071 & 0.212 \\
\hline 6 & 0.162 & 0.071 & 0.115 \\
\hline 7 & & 0.036 & \\
\hline
\end{tabular}




\section{Continued}

\begin{tabular}{|c|c|c|c|}
\hline 8 & 0.103 & 0.179 & 0.0154 \\
\hline 9 & 0.103 & 0.036 & 0.096 \\
\hline 10 & 0.191 & 0.214 & 0.212 \\
\hline 11 & 0.015 & 0.071 & \\
\hline 12 & 0.029 & 0.036 & 0.019 \\
\hline 13 & 0.015 & 0.071 & \\
\hline 14 & 0.044 & & \\
\hline 15 & 0.015 & & 0.039 \\
\hline 16 & 0.029 & & 0.039 \\
\hline 17 & 0.029 & 0.071 & \\
\hline 18 & 0.015 & & 0.019 \\
\hline 19 & 0.029 & & \\
\hline 20 & 0.015 & & \\
\hline CA12 & $\mathrm{AB}$ & $\mathrm{AB} 1$ & $\mathrm{AB} 2$ \\
\hline 1 & & & 0.019 \\
\hline 2 & 0.227 & & 0.222 \\
\hline 3 & 0.015 & & 0.056 \\
\hline 4 & 0.197 & 0.039 & 0.056 \\
\hline 5 & 0.046 & 0.192 & 0.056 \\
\hline 6 & 0.076 & 0.077 & 0.130 \\
\hline 7 & 0.106 & 0.462 & 0.185 \\
\hline 8 & 0.152 & & \\
\hline 9 & 0.076 & 0.115 & 0.148 \\
\hline 10 & 0.061 & 0.039 & 0.093 \\
\hline 11 & & 0.077 & \\
\hline 12 & 0.030 & & 0.037 \\
\hline 13 & 0.015 & & \\
\hline
\end{tabular}

Appendix 4. Observed and expected heterozygosity and tests of Hardy-Weinberg equilibrium at each site for seven polymorphic microsatellite loci.

\begin{tabular}{|c|c|c|c|c|c|c|}
\hline \multirow[b]{2}{*}{ Locus } & \multicolumn{2}{|c|}{$A B$} & \multicolumn{2}{|c|}{$\mathrm{AB} 1$} & \multicolumn{2}{|c|}{ AB2 } \\
\hline & $\begin{array}{c}\text { Observed } \\
\text { Heterozygosity }\end{array}$ & $\begin{array}{c}\text { Expected } \\
\text { Heterozygosity }\end{array}$ & $\begin{array}{c}\text { Observed } \\
\text { Heterozygosity }\end{array}$ & $\begin{array}{c}\text { Expected } \\
\text { Heterozygosity }\end{array}$ & $\begin{array}{c}\text { Observed } \\
\text { Heterozygosity }\end{array}$ & $\begin{array}{c}\text { Expected } \\
\text { Heterozygosity }\end{array}$ \\
\hline Rhca15b & $1.000^{\star * *}$ & 0.507 & $1.000^{\star * *}$ & 0.519 & $0.889^{* * *}$ & 0.503 \\
\hline Rhca16 & 0.029 & 0.029 & 0.077 & 0.077 & $0.111^{*}$ & 0.175 \\
\hline BD165 & 0.853 & 0.691 & $0.071^{\star *}$ & 0.362 & $0.074^{* * *}$ & 0.143 \\
\hline BD174 & 0.971 & 0.905 & 0.857 & 0.907 & 0.923 & 0.881 \\
\hline $\mathrm{Ca} 3$ & 0.941 & 0.907 & 0.929 & 0.918 & 0.885 & 0.875 \\
\hline Ca 12 & $0.7576^{\star * *}$ & 0.870 & 0.615 & 0.751 & 0.778 & 0.874 \\
\hline
\end{tabular}

${ }^{\star} P<0.01,{ }^{* *} P<0.001,{ }^{* * *} P<0.0001$. 